\title{
Nip New Disease Reports \\ First report of frosty pod rot caused by Moniliophthora roreri on cacao in Bolivia
}

\author{
W. Phillips-Mora ${ }^{1}$, F. Baqueros ${ }^{2}$, R.L. Melnick ${ }^{3 *}$ and B.A. Bailey ${ }^{3}$ \\ ${ }^{1}$ Tropical Agricultural Research and Higher Education Centre, PO Box 7170 CATIE, Turrialba, Costa Rica; ${ }^{2}$ CATIE, Avenida \\ Landaeta No 523, esquina con Abdón Saavedra. Edificio San Javier, piso 5, Sopocachi, La Paz, Bolivia; ${ }^{3}$ USDA-Agricultural \\ Research Service, Sustainable Perennial Crops Lab, 10300 Baltimore Avenue, Beltsville, MD 20705, USA
}

*E-mail: rachelmelnick@gmail.com

Received: 01 Apr 2015. Published: 14 Jun 2015. Keywords: basidiomycete, fungal plant disease

Frosty pod rot (FPR) is a devastating cacao disease caused by the basidiomycete Moniliophthora roreri (Aime \& Phillips-Mora, 2005). The disease is confined to 13 countries in Central and South America and constitutes a permanent threat for cacao cultivation worldwide. In July 2012, FPR was detected in Alto Beni, La Paz Department, Bolivia where $85 \%$ of cacao production is produced by approximately 3000 small-holders. Typical FPR symptoms and signs were observed in the villages of San Luis, Villa Prado y 3 de Mayo (Area III) and Litoral, San Antonio and Porvenir (Area IV). Symptoms included premature ripening, deformation, chocolate brown lesions and mummies (dehydrated, sporulated pods). Some lesions were covered by the distinctive mycelium. When cut in half, infected pods showed internal necrotic lesions. The fungus was aseptically isolated from necrotic lesions and grown on $20 \%$ modified V8 agar. Cultures of six isolates were sent to the USDA-ARS Sustainable Perennial Crops Lab in Beltsville, MD (Collection Accessions B1a, B1b, B1a, B2b, B3, and B4). Initially, the colonies had white growth that rapidly became cream coloured. After roughly 12 days, cultures became dark brown at the centre as they bore a massive amount of spores. Spores were examined microscopically. Spores were thick-walled and produced in chains with most being globose/subglobose $(87 \%)$ and some ellipsoid $(12 \%)$ in shape. Spores ranged in size from $7-11 \times 8-11 \mu \mathrm{m}$, with the average being $9.4 \mathrm{x}$ $9.6 \mu \mathrm{m}$. The morphological observations agree with the descriptions by Cifferi \& Parodi (1933) and Evans (1981).

PCR amplification was done with fungal specific primers ITS1-F/ITS (ITS) and LSU4-B/LR6pf roreri (Aime \& Phillips-Mora, 2005) to amplify the internal transcribed spacer region (ITS) and 28S - large ribosomal subunit (LSU). Sequencing of the isolates (GenBank Accession Nos. JX315272-JX515298) confirmed the presence of M. roreri in Bolivia (Fig. 1) and their genetic affinity to the Orientalis group, which also comprises isolates from Colombia, Venezuela, Ecuador and Peru (Phillips-Mora et al. (2007). Current average losses are estimated in 54\% in Alto Beni, but many other wild and cultivated cacao populations are now threatened by the disease.

\section{References}

Aime MC, Phillips-Mora W, 2005. The causal agents of witches' broom and frosty pod rot of cacao (chocolate, Theobroma cacao) form a new lineage of Marasmiaceae. Mycologia 97, 1012-1022. http://dx.doi.org/10.3852/mycologia.97.5.101

Cifferi R, Parodi E, 1933. Descrizione del fungo che causa la 'moniliase' del cacao. Phytopathologische Zeitschrift 6, 539-542.

Evans HC, 1981. Pod rot of cacao caused by Moniliophthora (Monilia) roreri. Phytopathological Papers No. 24. Kew, Surrey, UK, Commonwealth Mycological Institute, Kew.

Phillips-Mora W, Aime MC, Wilkinson MJ, 2007. Biodiversity and biogeography of the cacao (Theobroma cacao) pathogen Moniliophthora roreri. Plant Pathology, 56, 911-922. http://dx.doi.org/10.1111/j.1365-3059.2007.01646.x

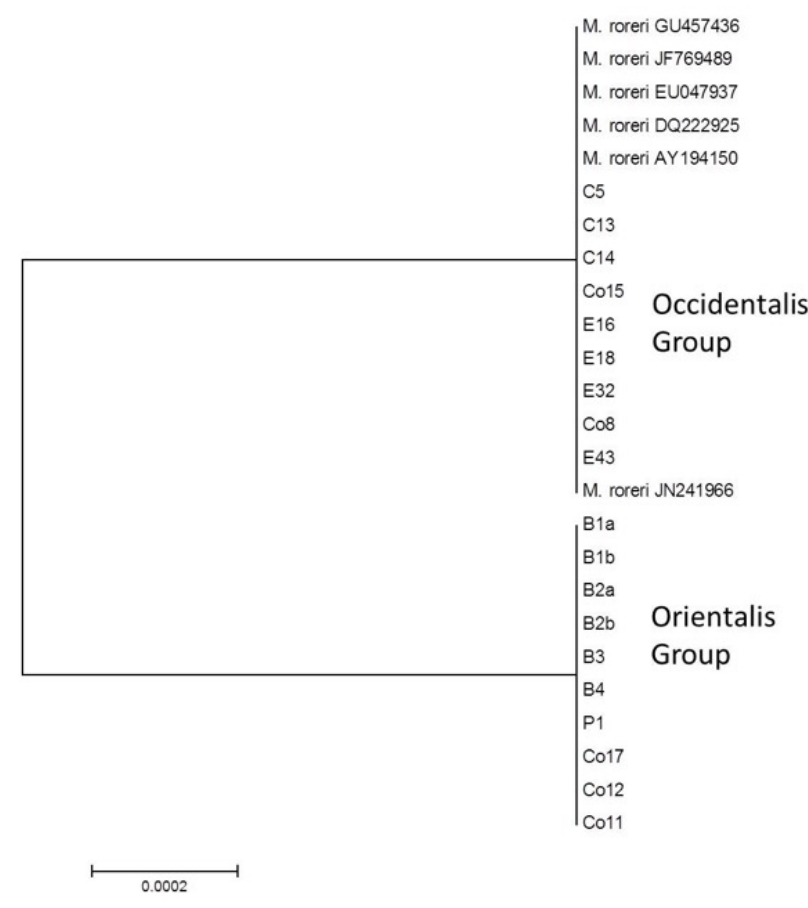

Figure 1

To cite this report: Phillips-Mora W, Baqueros F, Melnick RL, Bailey BA, 2015. First report of frosty pod rot caused by Moniliophthora roreri on cacao in Bolivia. New Disease Reports 31, 29. http://dx.doi.org/10.5197/j.2044-0588.2015.031.029 